\title{
Presumed Dead
}

National Cancer Institute

\section{Source}

National Cancer Institute. Presumed Dead. NCI Thesaurus. Code C99798.

The status of an individual who in all likelihood is not living, but has not been officially declared dead. 